\title{
EFFECT OF FASTING REGIMEN AND DIETARY ZINC SUPPLEMENTATION ON HEMATOLOGICAL PARAMETERS, HORMONAL PROFILES AND ANTIOXIDANT PROPERTIES IN MALES OF GROWING RABBITS
}

\author{
H. S. Zeweil ${ }^{1}$; S.M. Zahran'; T.A. Ebeid ${ }^{3,4}$; M.E. Elspeiy ${ }^{2}$; Yassmine M. El-Gindy $^{1}$ and \\ M.A. Abd-Elaal ${ }^{2}$
}

${ }^{I}$ Dept.of Anim and Fish prod., Fac. of Agric. (Saba Bash), Alexandria Univ., Alexandria, Egypt.

${ }^{2}$ Waterfowl and Rabbit Breeding Dep., Anim. Prod. Res. Institute, Agric. Res. Cent., Egypt.

${ }^{3}$ Dept. of Poult. Prod., Fac. of Agric., Kafrelsheikh Univ., 33516 Kafr El-Sheikh, Egypt.

${ }^{4}$ Dept. of Anim. Prod. and Breed. Coll. of Agric. and Vet. Med., Qassim Univ., 51452 Buraydah, Saudi Arabia.

(Received 2/2 / 2017, Accepted 21/3 /2017)

\section{SUMMARY}

\begin{abstract}
he objective of the present study was to evaluate the effect of fasting regimen and dietary zinc ( $\mathrm{Zn}$ ) supplementation on hematological parameters, blood biochemical components, hormonal profiles and the antioxidative properties in males of growing rabbits. A total of 60 weaned male V-Line rabbits (35 days old) were randomly divided into six experimental treatments (10 each): (1) control (basal diet ad labium without any supplementation of $\mathrm{Zn}$ ); (2) Ad+Zn (basal diet ad labium $+100 \mathrm{mg} \mathrm{Zn} / \mathrm{kg}$ diet); (3) F24 ( $24 \mathrm{hr}$ fasting regimen per week); (4) F48 (48 hr fasting regimen per week); (5) F24+Zn (24 hr fasting regimen per week+100 mg Zn/kg diet) and (6) $\mathrm{F} 48+\mathrm{Zn}$ (48 hr fasting regimen per week+100 mg Zn/kg diet). All experimental treatments were provided from 35 to 84 day of age. The obtained results showed that fasting regimen (in experimental groups F24 and F48) decreased significantly red blood cells (RBCs) compared with those of control $(\mathrm{Ad})$ or $\mathrm{Ad}+\mathrm{Zn}$ groups in growing rabbits $(P \leq 0.0001)$. While, group F48 recorded the lowest value of blood hemoglobin concentration $(\mathrm{Hb})$ and packed cell volume (PCV). Dietary Zn supplementation relieved the effect of fasting in groups F24+Zn and F48+Zn. Regarding to white blood cells (WBCs) count, the lowest WBCs number was observed in F48 group compared with other treatments. The highest neutrophils percentages were recorded in groups supplemented with $\mathrm{Zn}$ (in groups $\mathrm{Ad}+\mathrm{Zn}, \mathrm{F} 24+\mathrm{Zn}$ and F48+Zn) compared with the other groups. No significant differences were observed in lymphocytes (\%) monocytes (\%) eosinophils (\%) and basophils (\%) among the experimental groups. Feeding growing rabbit's ad libitum diet supplemented with $\mathrm{Zn}(\mathrm{Ad}+\mathrm{Zn})$ increased significantly blood plasma total protein and albumin concentration comparing with the other experimental groups. However, fasting regimen groups with or without $\mathrm{Zn}$ supplementation decreased significantly plasma total protein, albumin, glucose, total lipids, cholesterol and numerically triglycerides concentrations comparing with those fed ad libitum diet with or without $\mathrm{Zn}$ supplementation. Growing rabbits exposed to fasting (F24, F48, F24+Zn and F48+Zn groups) had a significant increase in blood plasma aspartate aminotransferase (AST), while, growing rabbits exposed to fasting with $\mathrm{Zn}$ (F24 and F48 groups) had a significant increase in blood plasma alanine aminotransferase (ALT) compared with those fed ad libitum diet with or without $\mathrm{Zn}$ supplementation (Ad and $\mathrm{Ad}+\mathrm{Zn}$ groups). Total antioxidant capacity (TAC) was significantly increased in the group fed ad libitum diet supplemented with $\mathrm{Zn}(\mathrm{Ad}+\mathrm{Zn})$ compared with the other experimental groups. However, TAC was significantly reduced in growing rabbit subjected to fasting regimen $(24$ or $48 \mathrm{~h})$ and dietary $\mathrm{Zn}$ supplementation alleviated this effect and improved TAC significantly. Growing rabbits exposed to fasting (F24, F48, F24+Zn and F48+Zn groups) had a significant increase in plasma malonylaldhyed (MDA) concentration, cortisol, corticosterone and significantly decrease in blood plasma triiodothyronine $\left(\mathrm{T}_{3}\right)$, thyroxin $\left(\mathrm{T}_{4}\right)$ compared with those fed ad libitum diet (Ad) and ad libitum diet $+\mathrm{Zn}$ $(\mathrm{Ad}+\mathrm{Zn})$. It could be concluded that growing rabbits exposed to fasting and fed diet supplemented with or without $\mathrm{Zn}$ had a significantly decrease in RBCs, $\mathrm{Hb}$ concentration, PCV, plasma total protein, albumin, glucose, total lipids, cholesterol, triglycerides, $\mathrm{T}_{3}$ and $\mathrm{T}_{4}$ concentrations. Interestingly, dietary $\mathrm{Zn}$ supplementation improved the antioxidative properties and reduced the rate of lipid peroxidation in growing rabbits subjected to fasting regimen.
\end{abstract}

Key words: Fasting, zinc, blood parameter, hormonal profile, antioxidative properties, growing rabbits. 


\section{Zeweil et al.}

\section{INTRODUCTION}

Weaning period is stressful for the kits due to separation from the dam, milk withdrawal and the change to solid feed. These changes can increase the susceptibility of rabbits to trouble on digestive tracts and the microbial count diseases (Gallois et al., 2008). De Blas (2013) stated that the weaning stage is a critical phase of development of digestive disorders, presumably caused by insufficient development of digestive enzymatic capability at an early age. Moreover, for the young mammal, the weaning and the post weaning period are particularly important for the growth performances and feed efficiency (Gidenne et al., 2009; Tůmová et al., 2016). The quantitative feed restriction for growing rabbits reduces the incidence of digestible disorders, particularly epizootic rabbit enteropathy (Debray et al., 2003). In rabbit production, specific and nonspecific enteropathies are always a concern, leading to animal losses of approximately 30\% from birth to slaughter (Gidenne and Fortun-Lamothe, 2002). Moreover, feed restriction might positively affect the several changes on metabolic disorders that lead to lower body weight, hormonal changes, immune depression and alter function of the digestive system, especially the liver and small intestine (Tůmová et al., 2016). Furthermore, fasting period could rapidly restore the morphology and functions of the intestine, repairing the intestinal atrophy and normalizing the permeability of the mucosa (Maria et al., 2013).

Zinc $(\mathrm{Zn})$ is a vital trace element found in small amounts in a variety of cells and tissues of organisms and plays an essential role in several biological functions such as protein synthesis, DNA synthesis (Prasad, 1995), immune function (Solomons, 1998), metabolic activities, productive performance like growth (Underwood and Suttle, 1999) and it is a cofactor of more than 300 enzymes (Tapiero and Tew, 2003). Zlotkin et al. (1995) found that dietary $\mathrm{Zn}$ has an important component of their functions of hormones and special physiological process including catalytic, structural and regulatory activities in which they interact with macromolecules such as enzymes, pro-hormones, pre-secretory granules and biological membranes.

Research on the changes in the blood laboratory indicators under the conditions of feeding stress has been done in rabbits (Peng and Coon, 1998). Most of the reported data about the observed changes under fasting conditions are controversial, since the factors of interest are appreciably effectiveness from the duration of the fasting period (starvation), the different types of digestion in mono- and polygastric animals, breed and age related peculiarities as well as various other factors (Aro et al., 2013). Therefore, the objective of the present study was to evaluate the effect of fasting regimen and dietary $\mathrm{Zn}$ supplementation on hematological parameters, blood biochemical components, hormonal profiles and antioxidative properties in males of growing rabbits.

\section{MATERIALS AND METHODS}

\section{Housing and management}

This study was carried out at the Rabbits Research Farm of El-Sabahia, Animal Production Research Institute, Agriculture Research Center, Egypt. Sixty weaned males V-line rabbits (35 days old) with an average live body weight of $535 \pm 11.25 \mathrm{~g}$, were distributed randomly into six treatments ( $\mathrm{n}=10$ each). Rabbits were housed in a naturally ventilated building and kept in individual wire galvanized battery (60 $\times 55 \times 40 \mathrm{~cm}$ ). Batteries were accommodated with feeders for pelleted rations and automatic drinkers. Fresh water was offered ad labium. The basal diet was formulated to meet the recommended nutrient requirements of growing rabbits according to De Blas and Mateos (1998). Rabbits were fed ad labium the standard pellet basal diet containing $17 \%$ crude protein, $2.56 \%$ crude fat, $12.5 \%$ crude fiber and 2500 Kcal digested energy/ kg-ration. Chemical analyses of the basal diet were carried out according to AOAC (2000) for crude protein, crude fiber, organic matter and ether extract. Animals were kept under similar management and hygienic conditions. Animals were healthy and clinically free of external and internal parasites. The lighting program provided $18 \mathrm{hrs}$ of light per day.

\section{Experimental design}

Group 1: Rabbits were fed commercial diet ad labium and served as control group (Ad).

Group 2: Rabbits were fed commercial diet ad labium +100 mg Zn) Zinc Sulfate, El-Nasr for pharm chemical, Egypt) kg diet (Ad+Zn). 
Group 3: Rabbits were fasted for $24 \mathrm{hr}$ each week (F24).

Group 4: Rabbits were fasted for $48 \mathrm{hr}$ (24hr at start of the week and the other $24 \mathrm{hr}$ after two days at the same week) each week throughout the experimental period (F48).

Group 5: Rabbits were fasted for $24 \mathrm{hr}$ each week $+100 \mathrm{mg} \mathrm{Zn/kg} \mathrm{diet} \mathrm{(F24+Zn).}$

Group 6: Rabbits were fasted for $48 \mathrm{hr}$ (24hr at start of the week and the other $24 \mathrm{hr}$ after two days at the same week) each week $+100 \mathrm{mg} \mathrm{Zn/kg} \operatorname{diet}(\mathrm{F} 48+\mathrm{Zn})$.

At the last week of the experiment, all groups were fed freely.

\section{Blood sampling}

Blood samples were collected from marginal vein of each rabbits to evaluate hematological parameters and blood biochemical measurements. Blood samples were taken in heparinized tubes. Blood samples were centrifuged at $3000 \mathrm{rpm}$ for 15 minutes; clear plasma was separated and then stored at $20^{\circ} \mathrm{C}$ until analyses.

\section{Hematological parameters}

Red blood cells counts (RBC's), white blood cell counts (WBC's), packed cell volume (PCV, \%) and hemoglobin concentration $(\mathrm{Hb})$ were measured according to the method of Helper (1966). Differential leukocytes percentages were determined according to the method described by Lucky (1977).

\section{Blood biochemical constituents}

Blood plasma concentrations of total proteins and albumin was spectrophotometrically determined using commercial kits according to Gornall et al. (1949) and (Weichselaum 1946); respectively. While, globulin concentration was calculate by subtracting albumin concentration from total proteins. Plasma glucose was measured using the method of Hyvarinen and Nikkila (1962). Plasma creatinine was measured according to Cabaud and Wroblewski (1958). Plasma total lipids, triglycerides and cholesterol were measured using the method of Chabrol and Charonnat (1973), Fasati and Prencipe (1982) and Stein (1986); respectively. Blood ALT and AST were measured using the method of Reitman and Frankel (1957)

\section{Hormones assay}

Blood plasma concentrations of thyroxin $\left(T_{4}\right)$ and triiodothyronine $\left(T_{3}\right)$ were measured according to Abdel-Fattah et al. (2011) using radioimmunoassay (RIA) technique. Blood plasma concentrations of corticosterone and cortisol were evaluated using RIA, using the CORT kit (ICN Biomedical Inc., Costa) according to Palme et al. (1996).

\section{Antioxidative status and lipid peroxidation}

Total antioxidant capacity (TAC) and malonyaldehyde (MDA) were measured according to Koracevic et al. (2001) and Richard et al. (1992); respectively. All biochemical parameters were analyzed by commercially available kit methods. GNW-Model: SM-721Spectrophotometers, Absorbance Microplate Reader and other laboratory equipment aids were used for biochemical analysis. Moreover, each parameter was done according to the instructions of its

\section{Statistical analysis}

Data were subjected to ANOVA using the general linear models procedure of SAS (Statistical Analysis System, 2002). The differences among groups means were Duncan's multiple rang test (Duncan, 1955).

\section{RESULTS AND DISCUSSION}

\section{Hematological parameters}

Data presented in Table (1) illustrated the overall means of red blood cell count (RBCs), blood hemoglobin concentration $(\mathrm{Hb})$, packed cell volume (PCV) and white blood cell count (WBCs) of growing rabbits as affected by fasting period and dietary $\mathrm{Zn}$ supplementation. Fasting regimen in groups F24 and F48 decreased significantly RBCs $\_$and Hb concentration compared with those of control (Ad) or $\mathrm{Ad}+\mathrm{Zn}$ groups in growing rabbits $(P \leq 0.0001)$. 
Table (1): Effect of fasting (feed regimen) and dietary zinc supplementation on some blood hematological parameters of $\mathrm{V}$-line male rabbits at 84 days.

\begin{tabular}{|c|c|c|c|c|c|c|c|}
\hline Item & $\mathrm{C}(\mathrm{Ad})$ & $\mathrm{Ad}+\mathrm{Zn}$ & F24 & F48 & $\mathrm{F} 24+\mathrm{Zn}$ & $\mathrm{F} 48+\mathrm{Zn}$ & Sig \\
\hline RBCs & $6.33^{A}$ & $6.47^{\mathrm{A}}$ & $5.53^{\mathrm{C}}$ & $5.33^{\mathrm{C}}$ & $5.87^{\mathrm{B}}$ & $5.80^{\mathrm{B}}$ & $* * *$ \\
\hline$\left(10^{6} / \mathrm{mm}^{3}\right)$ & \pm 0.08 & \pm 0.08 & \pm 0.11 & \pm 0.09 & \pm 0.04 & \pm 0.04 & \\
\hline $\mathrm{Hb}$ & $12.67^{\mathrm{A}}$ & $12.87^{\mathrm{A}}$ & $11.97^{\mathrm{B}}$ & $10.73^{C}$ & $12.10^{\mathrm{B}}$ & $12.03^{\mathrm{B}}$ & $* * *$ \\
\hline PCV & $40.30^{\mathrm{B}}$ & $43.37^{\mathrm{A}}$ & $39.33^{\mathrm{CD}}$ & $37.47^{\mathrm{E}}$ & $39.90^{\mathrm{BC}}$ & $39.03^{\mathrm{D}}$ & $* * *$ \\
\hline$(\%)$ & \pm 0.04 & \pm 0.42 & \pm 0.09 & \pm 0.22 & \pm 0.07 & \pm 0.08 & \\
\hline
\end{tabular}

$A, B, C ., D$ Means with different superscripts in the same row, differ significantly $(P<0.0001)$. C(Ad): free feeding (ad libitum), Ad+Zn: free feeding (ad libitum) +100mg zinc $/ \mathrm{kg}$ diet , F24:Fasting feed $24 \mathrm{hr}$ each week, F48 :Fasting feed $48 \mathrm{hr}$ each week, F24+Zn : Fasting 24hr each week +100mg zinc/kg diet, F48+Zn: Fasting 48hr each week $+100 \mathrm{mgzinc} / \mathrm{kg}$ diet.

Fasting regimen in groups F48 with or without Zn decreased PCV\%. Regarding to WBCs, the lowest WBCs count were observed in F48 compared with other treatments. These results are in agreement with Ebeid et al. (2012) who indicated that due to feed restriction, erythrocyte number and $\mathrm{Hb}$ concentration were significantly reduced while mean cell volume (MCV) was significantly increased in growing rabbits. This reduction in $\mathrm{Hb}$ content was suggested to be due to the observed reduction in erythrocytes' counts. Also, Tůmová et al. (2007) concluded that haematocrit was significantly decreased by fasting (feed regimen) in rabbits. Similarly, Matsuoka et al. (2006) found that hematological examination of pregnant does (on gestation day 19) documented variations in several blood parameters only in animals subjected to regimen feeding at $20 \mathrm{~g} / \mathrm{head} / \mathrm{day}$. In the present study, it could be observed that the values of the haematological characteristics were within the physiological range described by Tůmová et al. (2007). Generally, hematological parameters are good indicator for productive performance and the physiological status of animals (Khan and Zafer, 2005), and for determine environmental stresses (Nse-Abasi et al., 2014). The reduction in $\mathrm{Hb}$ content was suggested to be due to the observed reduction in erythrocytes' counts (Table 1). On the other hand, Nafeaa et al. (2011) mentioned that no significant differences in $\mathrm{RBCs}, \mathrm{Hb}$ and PCV values between the control and feed-restricted groups. Also, El-Speiy et al. (2015) recorded that feed restriction had no significant effect on WBCs but erythrocyte count and $\mathrm{Hb}$ concentration were significantly reduced by feed restriction compared with the control group.

Results of the present study are in correspondence with those of El Hendy et al. (2001) who postulated that hematological parameters (included $\mathrm{Hb}, \mathrm{PCV}$ and total erythrocyte count) were significantly affected by $\mathrm{Zn}$ insufficiency. Similarly, Younas et al. (2015) resulted that $\mathrm{Hb}$ content significantly affected due to treatments rabbits with $\mathrm{Zn}$ and non- significant behavior for leukocytes was observed. Contrarily, Mahmood and Sarmad (2016) reported that no significant differences were observed in WBCs and RBCs among treated group with pure $\mathrm{Zn}$ and the control group. Bovera et al. (2012) reported that total WBCs count was not different among groups treated with Zn-bacitracin.

\section{White blood cells differential}

Data shown in Table (2) illustrated that the lowest significant neutrophils \% was detected in control group compared with the other experimental groups $(P \leq 0.01)$. It could be observed that no significant differences in the neutrophils percent between $A d+Z n, F 24+Z n$ and F48+ Zn groups. No significant differences were observed among the experimental treatments in lymphocyte, monocyte, esinophils and basophilis percentages. It might be speculated that fasting regimen and dietary $\mathrm{Zn}$ had a role in modulating the immune system in growing rabbits. Frakock et al. (1987) reported that feeding stress (fasting status) cases change in percentage of neutrophilia, eosinophilia, and monocytopenia are typical for the so-called "stress leukogramme", which is due to the increased endogenous production of cortisol from the adrenal glands. It has also been observed that $\mathrm{Zn}$ reduction deactivates the $\mathrm{T}$ lymphocytes thus reduces the phagocytic action of macrophages, failing the immunity and play important role in the formation of superoxide dismutase (SOD) and catalase (CAT) in liver that plays disease modification role (Faa et al., 2008). Also, Fukada et al. (2011) demonstrated that $\mathrm{Zn}$ inadequate intake in animals results in serious immunodeficiency, increased numbers of infections, increased severity of infections, neuronal and sensory dysfunctions. Therefore, maternal $\mathrm{Zn}$ level is one of the basic requirements for the normal function of concepts and trophoblast (Mistry and Williams, 2011). The deficiency of Zn impaired functions of NK (natural killer) cells, T and B cells, neutrophils and macrophages (phagocytosis). 
Table (2): Effect of fasting (feed regimen) and dietary zinc supplementation on leukocytes differentiation of $\mathrm{V}$-line male rabbits at 84 days.

\begin{tabular}{lccccccc}
\hline Item & $\mathrm{C}(\mathrm{Ad})$ & $\mathrm{Ad}+\mathrm{Zn}$ & $\mathrm{F} 24$ & $\mathrm{~F} 48$ & $\mathrm{~F} 24+\mathrm{Zn}$ & $\mathrm{F} 48+\mathrm{Zn}$ & $\mathrm{Sig}$ \\
\hline Neutrophils (\%) & $44.50^{\mathrm{C}}$ & $46.19^{\mathrm{AB}}$ & $45.57^{\mathrm{B}}$ & $45.57^{\mathrm{B}}$ & $46.73^{\mathrm{A}}$ & $47.93^{\mathrm{A}}$ & $* *$ \\
& \pm 0.29 & \pm 0.28 & \pm 0.15 & \pm 0.21 & \pm 0.40 & \pm 0.42 & \\
Lymphocytes (\%) & 44.10 & 43.13 & 43.59 & 43.68 & 43.37 & 43.70 & $\mathrm{NS}$ \\
& \pm 0.19 & \pm 1.59 & \pm 0.11 & \pm 0.23 & \pm .31 & \pm 0.40 & \\
Monocytes (\%) & 4.66 & 4.97 & 4.81 & 4.90 & 4.67 & 4.87 & $\mathrm{NS}$ \\
& \pm 0.04 & \pm 0.19 & \pm 0.23 & \pm 0.04 & \pm 0.08 & \pm 0.02 & \\
Eosinophils (\%) & 1.91 & 1.87 & 1.88 & 1.85 & 1.93 & 1.83 & $\mathrm{NS}$ \\
& \pm 0.04 & \pm 0.02 & \pm 0.02 & \pm 0.04 & \pm 0.17 & \pm 0.09 & \\
Basophils (\%) & 4.40 & 4.27 & 4.15 & 4.40 & 4.26 & 4.37 & NS \\
& \pm 0.06 & \pm 0.06 & \pm 0.04 & \pm 0.13 & \pm 0.19 & \pm .16 & \\
\hline
\end{tabular}

$A, B, C$ Means with different superscripts in the same row, differ significantly $(P<0.0001)$. $C(A d)$ : free feeding (ad libitum), Ad+Zn: free feeding (ad libitum) +100mg zinc /kg diet, F24:Fasting feed $24 \mathrm{hr}$ each week, F48 :Fasting feed $48 \mathrm{hr}$ each week, F24+Zn : Fasting 24hr each week +100mgzinc/kg diet, F48+Zn: Fasting 48hr each week $+100 \mathrm{mgzinc} / \mathrm{kg}$ diet.

This situation induces lymphopenia (less lymphocyte production) hence attacked by chronic pathogens, compromising immunity (Blewett and Carla, 2012). However, it has been documented that $\mathrm{Zn}$ helps in the formation and maturation of T-cells subsequently synthesizes IgA and IgG. Similarly, Zn supplementation was also found effective in restoring the function of $\mathrm{T}$ helper cells, if treated three weeks before immunization whilst, side effects were detected if consumed after vaccination (Haase et al., 2008).

\section{Blood biochemical constituents}

Results concerning the effect of fasting regimen on blood plasma biochemical constituents in growing rabbits are tabulated in Table (3). Growing rabbits fed ad libitum and supplemented with $\mathrm{Zn}$ $(\mathrm{Ad}+\mathrm{Zn})$ had a significant increase in blood plasma total protein, albumin and glucose. These improvements due to $\mathrm{Zn}$ supplementation are in agreement with Kalafova et al. (2008) who noticed that higher average concentrations of total proteins were measured in groups with $\mathrm{Zn}$ supplementation. However, Atakisi et al. (2009) documented that glucose and total protein levels were decreased in $\mathrm{Zn}$ supplemented animals compared to the control. Al-Mousawi (2013) stated that Zn administration significantly reduced the serum glucose.

In Table (3), fasting regimen groups with or without $\mathrm{Zn}$ supplementation decreased significantly blood plasma total protein, albumin, glucose, total lipids and cholesterol concentrations comparing with those fed ad libitum diet with or without $\mathrm{Zn}$ supplementation. These results are in agreement with several previous studies (Chilliard et al., 1998; Abeer et al., 2008; Matsuoka et al., 2009; Ebeid et al., 2012; ElSpeiy et al., 2015). Abeer et al. (2008) reported that total protein was significantly reduced in serum at late gestation period during feed restriction in NZW rabbits does. Matsuoka et al. (2009) noted that restricted feeding showed significantly lower values in many parameters such as total protein and albumin reflecting low nutritive condition. Also, Daoud et al. (2012) documented that the decreased levels of total protein, albumin and increasing creatinine concentration in NZW rabbits might be connected with feed restriction. These results are in accordance with El-Speiy et al. (2015) who confirmed that feed restriction caused significant decrease in blood plasma protein values compared with control group in growing rabbits.

As presented in Table (3) blood plasma glucose concentration was significantly reduced by feed restriction in growing rabbits. These results are in agreement with those of Dewil et al. (1999) who found that decrease in plasma glucose motivate by the short food restriction $(24 \mathrm{hr})$ in chickens. Similarly, Rommers et al. (2004) reported that during the restricted period, plasma glucose was constantly lower (P $<0.05$ ) in feed restriction groups. On the other hand, Ebeid et al. (2012) noted that blood plasma glucose concentration was not significantly affected by feed restriction in growing rabbits.

Data tabulated in Table (3) declare that feed restriction resulted in reducing blood plasma total lipids andcholesterol concentrations indicating lipid depletion of these experimental animals in the present study. 
Table (3): Effect of fasting (feed regimen) and dietary zinc supplementation on blood biochemical parameters of $\mathrm{V}$-line male rabbits at 84 days.

\begin{tabular}{|c|c|c|c|c|c|c|c|}
\hline Item & $\mathrm{C}(\mathrm{Ad})$ & $\mathrm{Ad}+\mathrm{Zn}$ & $\mathrm{F} 24$ & F48 & $\mathrm{F} 24+\mathrm{Zn}$ & $\mathrm{F} 48+\mathrm{Zn}$ & Sig \\
\hline Total protein & $6.16^{\mathrm{B}}$ & $6.60^{\mathrm{A}}$ & $5.60^{C}$ & $5.57^{\mathrm{C}}$ & $5.73^{C}$ & $5.70^{\mathrm{C}}$ & $* * *$ \\
\hline$(\mathrm{g} / \mathrm{dL})$ & \pm 0.09 & \pm 0.06 & \pm 0.06 & \pm 0.10 & \pm 0.06 & \pm 0.04 & \\
\hline Albumin & $3.83^{\mathrm{B}}$ & $4.20^{\mathrm{A}}$ & $3.27^{\mathrm{C}}$ & $2.99^{\mathrm{E}}$ & $3.43^{\mathrm{D}}$ & $3.33^{\mathrm{D}}$ & $* * *$ \\
\hline$(\mathrm{g} / \mathrm{dL})$ & \pm 0.11 & \pm 0.04 & \pm 0.10 & \pm 0.06 & \pm 0.06 & \pm 0.04 & \\
\hline Globulin & 2.33 & 2.40 & 2.33 & 2.58 & 2.30 & 2.37 & NS \\
\hline$(\mathrm{g} / \mathrm{dL})$ & \pm 0.02 & \pm 0.09 & \pm 0.04 & \pm 0.04 & \pm 0.02 & \pm 0.02 & \\
\hline Glucose & $114.67^{\mathrm{B}}$ & $119.33^{\mathrm{A}}$ & $105.33^{C}$ & $104.10^{C}$ & $106.00^{C}$ & $109.00^{\mathrm{C}}$ & $* * *$ \\
\hline (mg/dL) & \pm 0.76 & \pm 0.56 & \pm 0.92 & \pm 0.37 & \pm 0.37 & \pm 0.37 & \\
\hline Creatinine & 0.51 & 0.53 & 0.53 & 0.54 & 0.50 & 0.51 & NS \\
\hline (mg/dL) & \pm 0.04 & \pm 0.02 & \pm 0.02 & \pm 0.04 & \pm 0.02 & \pm 0.03 & \\
\hline Total lipids & $105.03^{\mathrm{A}}$ & $99.33^{\mathrm{B}}$ & $95.40^{\mathrm{C}}$ & 90.40 & $95.80^{\mathrm{C}}$ & 94.53 & $* * *$ \\
\hline$(\mathrm{mg} / \mathrm{dL})$ & \pm 0.61 & \pm 0.29 & \pm 0.33 & ${ }^{\mathrm{D}} \pm 0.86$ & \pm 1.93 & $\mathrm{C}_{ \pm 1.92}$ & \\
\hline Cholesterol & $195.93^{\mathrm{A}}$ & $166.57^{\mathrm{B}}$ & $147.9^{\mathrm{CD}_{3}}$ & $145.63^{\mathrm{D}}$ & $154.53^{\mathrm{C}}$ & $143.57^{\mathrm{D}}$ & $* * *$ \\
\hline$(\mathrm{mg} / \mathrm{dL})$ & \pm 2.12 & \pm 2.59 & \pm 0.86 & \pm 1.70 & \pm 5.10 & \pm 2.02 & \\
\hline Triglycerides & $39.30^{\mathrm{A}}$ & $33.90^{\mathrm{B}}$ & $33.80^{\mathrm{B}}$ & $31.23^{\mathrm{C}}$ & $30.90^{\mathrm{C}}$ & $30.63^{C}$ & $* * *$ \\
\hline$(\mathrm{mg} / \mathrm{dL})$ & \pm 0.45 & \pm 0.49 & \pm 0.19 & \pm 0.40 & \pm 0.16 & \pm 0.49 & \\
\hline ALT & $36.66^{\mathrm{B}}$ & $30.00^{\mathrm{E}}$ & $47.00^{\mathrm{A}}$ & $49.67^{\mathrm{A}} \pm$ & $41.00^{\mathrm{B}} \pm$ & $42.00^{\mathrm{B}}$ & $* * *$ \\
\hline$(\mathrm{U} / \mathrm{L})$ & \pm 0.56 & \pm 0.37 & \pm 0.37 & 0.76 & 0.37 & \pm 0.37 & \\
\hline $\mathrm{AST}$ & $25.33^{C}$ & $17.66^{\mathrm{D}}$ & $32.00^{\mathrm{A}}$ & $34.67^{\mathrm{A}}$ & $27.33^{\mathrm{A}}$ & $29.00^{\mathrm{B}}$ & $* * *$ \\
\hline (U/L) & \pm 0.56 & \pm 0.56 & \pm 0.37 & \pm 1.48 & \pm 0.76 & \pm 0.37 & \\
\hline
\end{tabular}

$A, B, C, D, E$ Means with different superscripts in the same row, differ significantly $(P<0.0001)$. $C(A d)$ : free feeding (ad libitum), Ad+Zn: free feeding (ad libitum) +100mg zinc / $\mathrm{kg}$ diet , F24:Fasting feed $24 \mathrm{hr}$ each week, F48 :Fasting feed $48 \mathrm{hr}$ each week, F24+Zn : Fasting 24hr each week +100mgzinc/kgdiet, F48+Zn: Fasting 48hr each week $+100 \mathrm{mgzinc} / \mathrm{kg}$ diet.

These results are in accordance with several previous studies (Rajman et al., 2006; van Harten and Cardoso, 2010; Ebeid et al., 2012). van Harten and Cardoso (2010) stated that feed restriction reduced significantly triacylglycerols, non-esterifed fatty acids and free fatty acids in rabbits and induced a higher lipidic depletion in these animals. Also, Rajman et al. (2006) confirmed that feed restriction decreased plasma concentrations of total lipids, triacylglycerols, cholesterol, and high density lipids. Similarly, Yassein et al. (2011) founded that feed restriction had dramatic changes in lipoprotein metabolism characterized by decreased triglycerides and remodeling of LDL and HDL cholesterol to form larger particles. In this context, Turturro et al. (1993) suggested that fat metabolism was significantly modified by feed restriction.

The main effects of fasting regimen and dietary Zn supplementation on blood plasma ALT and AST are shown in Table (3). Growing rabbits subjected to fasting (F24, F48, F24+Zn and F48+Zn groups) recorded significant increase in blood plasma AST compared with those fed ad libitum diet with or without $\mathrm{Zn}$ supplementation (Ad and Ad+Zn groups). The reduction in AST concentrations recorded are in harmony with the results obtained by Al-Mousawi (2013) who showed that supplemented with Zn significantly $(P<0.05)$ reduced the serum ALT and AST concentration in diabetic rabbits.

\section{Antioxidative status and lipid peroxidation}

Respecting to the influence of fasting regimen and dietary Zn supplementation on plasma TAC and MDA (Table 4), it could be noted that TAC was significantly increased in the group fed ad libitum diet supplemented with $\mathrm{Zn}(\mathrm{Ad}+\mathrm{Zn})$ compared with the other experimental groups. However, TAC was significantly reduced in growing rabbit subjected to fasting regimen (24 or $48 \mathrm{~h}$ ) and dietary $\mathrm{Zn}$ supplementation alleviated this effect and improved TAC significantly. It is noteworthy to indicate that growing rabbits exposed to fasting (F24, F48, F24+Zn and F48+Zn groups) had a significant increase in plasma MDA concentration which used as lipid peroxidation index; however, the lowest value was recorded for the group fed ad libitum diet and supplied with $\mathrm{Zn}(\mathrm{Ad}+\mathrm{Zn})$. $\mathrm{Zn}$ is a biologically important trace mineral with multiple functions because it is a cofactor of more than 300 enzymes in metabolic systems (Vallee and Falchuk, 1993). One of its important functions is participation in the antioxidant defense system (Powell, 2000). Dietary Zn status exerts a powerful influence on the degree of oxidative damage caused by free radicals (Tupe et al., 2010). Oxidative stress is manifested primarily via alterations of antioxidant enzyme activities and the reductions of some nonenzymatic antioxidants. Lipid peroxidation is an indication of oxidative damage of cells. 
Table (4): Effect of fasting (feed regimen) and dietary zinc supplementation on antioxidative properties and lipid peroxidation of $\mathrm{V}$-line male rabbits at 84 days.

\begin{tabular}{|c|c|c|c|c|c|c|c|}
\hline Item & $\mathrm{C}(\mathrm{Ad})$ & $\mathrm{Ad}+\mathrm{Zn}$ & F24 & F48 & $\mathrm{F} 24+\mathrm{Zn}$ & $\mathrm{F} 48+\mathrm{Zn}$ & Sig \\
\hline TAC & $140.87^{B}$ & $150.23^{A}$ & $113.20^{\mathrm{D}}$ & $103.07^{\mathrm{E}}$ & $133.63^{\mathrm{BC}}$ & $123.37^{C}$ & $* *$ \\
\hline$(\mathrm{mM} / \mathrm{L})$ & \pm 0.52 & \pm 0.48 & \pm 0.79 & \pm 0.97 & \pm 0.99 & \pm 1.02 & \\
\hline MDA & $54.33^{C}$ & $43.23^{D}$ & $62.97^{\mathrm{B}}$ & $73.40^{\mathrm{A}}$ & $64.20^{\mathrm{B}}$ & $63.23^{\mathrm{B}}$ & $* *$ \\
\hline$(\mathrm{nmol} / \mathrm{ml})$ & \pm 1.75 & \pm 0.80 & \pm 1.11 & \pm 1.34 & \pm 1.90 & \pm 1.59 & \\
\hline
\end{tabular}

$A, B, C ., D$ Means with different superscripts in the same row, differ significantly $(P<0.0001)$. C: free feeding (ad libitum),R1: free feeding (ad libitum) +100mg zinc / $\mathrm{kg}$ diet , $\boldsymbol{R 2}:$ Fasting feed $24 \mathrm{hr}$ each week, $\boldsymbol{R} 3$ :Fasting feed $48 \mathrm{hr}$ each week,R4: Fasting $24 \mathrm{hr}$ each week +100mgzinc/kgdiet, R5: Fasting 48hr each week +100mgzinc/kg diet. TAC= Total antioxidant capacity, $\mathbf{M D A}=$ Malonylaldhyed .

$\mathrm{Zn}$ can compete with iron and copper to bind to the cell membrane and decrease the production of free radicals, thus exerting a direct antioxidant action (Tate et al., 1999). Dietary Zn was reported to increase the $\mathrm{Cu}-\mathrm{Zn}$-superoxide dismutase activity in piglets (Wang et al., 2012). Bun et al. (2011) noted that activities of superoxide dismutase and glutathione peroxidase were increased $(\mathrm{P}<0.001)$ with increasing dietary $\mathrm{Zn}$ levels in broiler chickens, while, lipid peroxidation tended to be reduced $(\mathrm{P}=0.08)$ at $\mathrm{Zn}$ inclusion of 20 and $40 \mathrm{mg} / \mathrm{kg}$. Shaheen and El-Fattah (1995) reported that Zn deficiency caused increased lipid peroxidation and that this was overcome by Zn supplementation. Juda et al. (2007) found that orally $\mathrm{Zn}$ supplementations significantly decrease in serum concentration of MDA in comparison with control. Duzguner and Kaya (2007) concluded that daily Zn supplementation could reduce the harmful effects of oxidative (by reduce MDA) stress in diabetics rabbit.

\section{Hormones profile}

Results concerning the effects of fasting regimen and dietary Zn supplementation on serum adrenal cortex hormones (cortisol and corticosterone) and thyroid hormones $\left(\mathrm{T}_{3}\right.$ and $\mathrm{T}_{4}$ ) concentrations in growing rabbits are presented in Table (5). It is noteworthy to note that growing rabbits exposed to fasting (F24, F48, F24+Zn and F48+Zn groups) had a significant increase in blood plasma cortisol and corticosterone compared with those fed ad libitum diet (Ad) and ad libitum diet $+\mathrm{Zn}(\mathrm{Ad}+\mathrm{Zn})$. These results are agreement with the results reported by Mastorakos and Ilias (2003) and Zhang et al. (2011) who reported that plasma corticosterone is considered the main glucocorticoid involved in regulation of stress (eg., heat stress, fasting .....etc) responses in rodents, the presence of plasma cortical hormones and whether its level can be used as an indicator for rodent activation of stress remain to be determined. Cortisol secretion is a generic response to stress as well as a specific adaptive response to fasting and nutritional stress recruiting all available energy sources in the body. In the same line, Wu et al. (2012) observed that the plasma corticosterone concentration in mice that had been subjected to chronic unpredictable stress for 30 days was significantly higher than that in control mice. Also, Liu et al. (2013) observed a significant elevation of endogenous corticosterone levels in mice following a $24 \mathrm{~h}$ acute restraint stress reported that serum corticosterone levels in mice exposed to chronic stress for 21 days $(242.55 \mathrm{ng} / \mathrm{ml})$ increased significantly compared with those in unstressed control mice.

Table (5): Effect of fasting (feed regimen) and dietary zinc supplementation on some hormones function of $\mathrm{V}$-line male rabbits at 84 days.

\begin{tabular}{lccccccc}
\hline Item & $\mathrm{C}(\mathrm{Ad})$ & $\mathrm{Ad}+\mathrm{Zn}$ & $\mathrm{F} 24$ & $\mathrm{~F} 48$ & $\mathrm{~F} 24+\mathrm{Zn}$ & $\mathrm{F} 48+\mathrm{Zn}$ & Sig \\
Cortisol & $6.00^{\mathrm{D}}$ & $5.33^{\mathrm{DE}}$ & $9.03^{\mathrm{B}}$ & $11.67^{\mathrm{A}}$ & $7.73^{\mathrm{BC}}$ & $7.63^{\mathrm{BC}}$ & $* *$ \\
(ug/dL) & $\pm 0.33^{\mathrm{n}}$ & \pm 0.15 & \pm 1.95 & \pm 0.16 & \pm 0.13 & \pm 0.24 & \\
Corticosterone & $3.4^{\mathrm{D}}$ & $3.20^{\mathrm{D}} \pm$ & $5.33^{\mathrm{B}}$ & $6.03^{\mathrm{A}}$ & $4.67^{\mathrm{C}}$ & $5.23^{\mathrm{B}}$ & $* *$ \\
$(\mathrm{nmol} / \mathrm{ml})$ & \pm 0.08 & $0.07^{\mathrm{B}}$ & \pm 0.06 & \pm 0.02 & \pm 0.06 & \pm 0.06 & \\
$\mathrm{~T} 3$ & $1.80^{\mathrm{B}}$ & $2.30^{\mathrm{A}}$ & $1.10^{\mathrm{CD}}$ & $0.83^{\mathrm{D}}$ & $1.40^{\mathrm{C}}$ & $1.03^{\mathrm{CD}}$ & $* *$ \\
$(\mathrm{ng} / \mathrm{ml})$ & \pm 0.22 & \pm 0.07 & \pm 0.09 & \pm 0.10 & \pm 0.10 & \pm 0.34 & \\
$\mathrm{~T} 4$ & $5.13^{\mathrm{B}}$ & $6.57^{\mathrm{A}}$ & $2.50^{\mathrm{E}}$ & $2.27^{\mathrm{E}}$ & $3.43^{\mathrm{C}}$ & $2.93^{\mathrm{D}}$ & $* *$ \\
$(\mathrm{ug} / \mathrm{dl})$ & \pm 0.09 & \pm 0.22 & \pm 0.04 & \pm 0.06 & \pm 0.06 & \pm 0.06 & \\
\hline
\end{tabular}

$A, B, C ., D$ Means with different superscripts in the same row, differ significantly $(P<0.0001)$.

$C(A d)$ : free feeding (ad libitum), Ad+Zn: free feeding (ad libitum) +100mg zinc /kg diet, F24:Fasting feed $24 \mathrm{hr}$ each week, F48 :Fasting feed 48 hr each week, F24+Zn : Fasting $24 \mathrm{hr}$ each week +100mgzinc/kgdiet, F48+Zn: Fasting 48hr each week $+100 \mathrm{mgzinc} / \mathrm{kg}$ diet., Corticosterone $=$ Cortic, Triiodothyronine $=T 3$, Thyroxine $=T 4$ 


\section{Zeweil et al.}

As shown in Table (5), fasting regimen and fed diet supplemented with or without Zn (F24, F48, F24+Zn and F48+Zn groups) had significantly decrease in blood plasma $T_{3}$ and $T_{4}$ compared with those fed ad libitum diet $(\mathrm{Ad})$ and ad libitum diet $+\mathrm{Zn}(\mathrm{Ad}+\mathrm{Zn})$ in growing rabbits. It is well known that feed restriction is involved in the regulatory mechanisms of metabolism in animals. In this context, Suda et al. (1978) recorded that calorie deprivation leads to reduction in serum $\mathrm{T}_{3}$ is caused by a reduction in its generation from $T_{4}$ rather than by an acceleration in its metabolic clearance rate. The decline in $T_{3}$ concentration is accompanied by a concomitant and reciprocal change in the concentration of total and free $T_{3}$. The increase in the serum $T_{3}$ concentration tends to begin later and to return to normal at the time serum $\mathrm{T}_{3}$ is being maintained at a low level with continuous. Also, Rommers et al. (2002) reported that long-term nutrient deficiency during development has major neuro-endocrine consequences trigger prominent homeostatic reactions of the corticotrophin, somatotropic, leptinergic and thyrotrophic axes. In contrast, Chan et al. (2006) reported that seventy-two-hour fasting significantly decreased free $\mathrm{T}_{3}$, increased reverse $T_{3}$, and markedly suppressed several parameters of TSH pulsatility, whereas free $\mathrm{T}_{4}$ remained stable. The role of $\mathrm{Zn}$ for improvement metabolism and thyroid hormones is reported by Nishiyama et al. (1994) who demonstrated that $\mathrm{Zn}$ is a cofactor for iodothyronine iodinase (IDI) enzyme, the enzyme that convert $\mathrm{T}_{4}$ hormone to $\mathrm{T}_{3}$. Zn may play a role in thyroid hormones metabolism in patients with low levels of $\mathrm{T}_{3}$ hormone and may control the conversion of $\mathrm{T}_{4}$ to $\mathrm{T}_{3}$ in human (Christy and Stella, 2007). Also, Maxwell and Volpe (2007) reported that $\mathrm{Zn}$ supplementation appeared to have a favorable effect on thyroid hormones levels, particularly total $\mathrm{T}_{3}$. Moreover, Ertek et al. (2010) showed that $\mathrm{Zn}$ levels were significantly positively correlated with free $\mathrm{T}_{3}$ levels $(P<0.001)$. Similarly, Zearah et al. (2016) showed that the elevation of total $\mathrm{T}_{4}$ and total $\mathrm{T}_{3}$ level after the intake of $\mathrm{Zn}$ supplementation and this elevation was highly significant $(\mathrm{P}<0.001)$ and it has important role to increase $\mathrm{T}_{3}$.

\section{CONCLUSION}

Based on the data presented above, it could be concluded that growing rabbits exposed to fasting and fed diet supplemented with or without $\mathrm{Zn}$ had a significantly decrease in RBCs, Hb concentration, PCV, plasma total protein, albumin, glucose, total lipids, cholesterol, triglycerides, T3 and T4 concentrations. Interestingly, dietary $\mathrm{Zn}$ supplementation improved the antioxidative properties and reduced the rate of lipid peroxidation in growing rabbits subjected to fasting regimen.

\section{REFERENCES}

Abdel-Fattah. A.A.; K.M. Sallam and K.A. Moustafa (2011). A novel method for determination of T3 and T4 hormones, associated with its physicochemical studies. Radiochemistry, 53: 213-220.

Abeer, E. Mansour and A.Z. Hegazi (2008). The immune response of different farm animals vaccinated with bivalent FMD vaccine. Egyptian J. Virol., 5: 260-270.

Al-Mousawi Zainab, A. (2013). Effect of vitamin C and zinc on some biochemical parameter in alloxan induced diabetic rabbit. Bas. J. Vet. Res., 12: 77-84.

AOAC (2000). Association of Official Analytical Chemists. Official Methods of Analysis (Seventeenth Edition). Washington, DC.

Aro, S.O.; F.F. Ogunwaleand and O.A. Falade (2013). Blood viscosity of finisher cockerel fed dietary inclusions of fermented cassava tuber wastes. Proc. of the $18^{\text {th }}$ Annual Conf. of Anim. Sci. Assoc. of Nig., 74-77.

Atakisi, E.; O. Atakisi; B. Topcu and M. Uzun (2009). Effects of therapeutic dose of ivermectin on plasma nitric oxide and total antioxidant capacity in rabbits. Eur. Rev. Med. Pharmacol. Sci., 13: 425-429.

Blewett, H.J. and G.T. Carla (2012). Dietary Zinc Deficiency in Rodents: Effects on T-Cell Development, Maturation and Phenotypes. Nutr. 4: 449-466.

Bovera, F.; A. Lestingi; S. Marono; F. Iannaccone; S. Nizza; K. Mallardo; L. de Martino and A. Tateo (2012). Effect of dietary mannan oligosaccharides on in vivo performance, nutrient digestibility and caecal content characteristics of growing rabbits. J. Anim. Phys. Anim. Nut., 96: 130-136. 
Bun, S. D., Y. M. Guo, F. C. Guo, F. J. Ji, and H. Cao (2011). Influence of organic zinc supplementation on the antioxidant status and immune responses of broilers challenged with Eimeria tenella. Poult. Sci. 90: 1220-1226

Chabrol, E. and Charonnat, R. (1973). Determination of plasma total lipids. Press medical, 45: 17131720.

Chan, J.L., G. Matarese; G.K. Shetty; P. Raciti; I.K. Aufiero; V.D. Rosa; F. Perna, S. Fontana and C.S. Mantzoros (2006). Differential regulation of metabolic, neuroendocrine, and immune function by leptin in humans. PNAS., 103: 8481-8486.

Chilliard, Y.; F. Bocquier and M. Doreau (1998). Digestive and metabolic adaptations of ruminants to undernutrition, and consequences on reproduction. Reprod. Nut. Develop. 38: 131-152.

Christy, L.V. and Stella (2007). Effect of zinc supplementation on thyroid hormone function: A case study of two college females. Ann. Nutr. Metab., 51: 188-194.

Daoud Niveen M.; Azza H. Abd-El-Rahman; Karima F.M; W.B. Khalil and H. Ezzo (2012). GDF-9 gene expression, oocyte quality, hematological and biochemical Profiles affected by feed restriction as a biostimulant method on rabbits' fertility. Global Veterinaria, 8: 532-540.

De Blas, J.C. (2013). Nutritional impact on health and performance in intensively reared rabbits. Animal 7: $102-111$.

De Blas, J.C. and G.G. Mateos (1998). Feed formulation. In: De Blas J.C., Wiseman J. (ed) The Nutrition of the Rabbit. Ed CABI Publishing, UK, 241-254.

Debray L., Le Huerou-Luron I, Gidenne T, Fortun-Lamothe L. (2003). Digestive tract development in rabbit according to dietary energetic source: correlation between whole tract digestion, pancreatic and intestinal enzymatic activities. Comp. Biochem. Physiol., 135: 443-455.

Dewil, E.; V.M. Darras; G.S. Spencer; T.J. Lauterio and E. Decuypere (1999). The regulation of GH dependent hormones and enzymes after feed restriction in dwarf and control chickens. Life Sci., 64: 1359-1371.

Duncan, D. B. (1955). Multiple range and multiple F tests. Biometrics 11:1-42.

Duzguner, V. and S. Kaya (2007). Effect of zinc on the lipid peroxidation and the antioxidant defense systems of the alloxan-induced diabetic rabbits. Free Radic Biol. Med. 42: 1481-1486.

Ebeid T., Tůmová E., and Volek, Z. (2012). Effects of a one week intensive feed restriction in the growing rabbit: Part 1 - Performance and blood biochemical parameters. The $10^{\text {th }}$ World Rabbit Congress, 3-6 September 2012, Sharm El-Sheikh, Egypt, pp 607-611.

El Hendy, H.A.; Mokhtar I.Y and N.A. (2001). Effect of dietary zinc deficiency on hematological and biochemical parameters and concentrations of zinc, copper and iron in growing rats. Toxicology, 167:163-170.

El-Speiy, M.E.; K.I. Kamel; A.E. Tag El-Din and A.E. Abd- Hamid and A. EL-Kamhawey (2015). Effect of feed restriction on productive performance, carcass yield, blood pictures and relative organ weights of growing rabbits. Egyptian Poult. Sci. 35: 439-454.

Ertek, S.1.; A.F. Cicero; O. Caglar and G. Erdogan (2010). Relationship between serum zinc levels, thyroid hormones and thyroid volume following successful iodine supplementation. Hormones (Athens). 9: 263-268.

Faa, G.; M.N. Valeria; R. Alberto; F. Daniela; N. Sonia; G. Clara; V.E. Peter and G. Karel (2008). Zinc in gastrointestinal and liver disease. Coor. Chem. Rev., 252: 1257-1269.

Fasati P. and L. Prencipe (1982). Determination of plasma triglycerides. Clinical. Chem., 28: 2077

Frakock, M.D.; D.A. Jessup; R.K. Clark and C.E. Franti (1987). Effects of capture on biological parameters in free ranging bighorn sheep (Oviscanadensis): evaluation of drop-net, drive-net, chemical immobilization and the net-gun. J. Wildl. Dis., 23: 641-651.

Fukada, T.; S. Yamasaki; K. Nishida; M. Murakami and T. Hirano (2011). Zinc homeostasis and signaling in health and diseases. J. Biol. Inorg. Chem. 16: 1123-1134. 


\section{Zeweil et al.}

Gallois M, Le Huërou-Luron I, Fortun-Lamothe L, Lallès JP, Gidenne T. (2008). Adaptabilidade of the digestive function according to age at weaning in the rabbit: I. Effect on feed intake and digestive functionality. Animal, 2: 525-535.

Gidenne, T. and L. Fortun-Lamothe (2002). Feeding strategy for young rabbits around weaning: a review of digestive capacity and nutritional needs. Animal Sci., 75: 169-184.

Gidenne, T., Combes, S., Feugier, A., Jehl, N., Arveux, P., Boisot, P., Briens, C., Corrent, E., Fortune, H., Montessuy, S., and Verdelhan, S. (2009). Feed restriction strategy in the growing rabbit. 2. Impact on digestive health, growth and carcass characteristics. Animal 3:509-515.

Gornall, A.G.; C.J. Bardawill and M.M. David (1949). Determination of serum protein by means of the biuret reaction. J. Biol. Chem., 177: 751-766.

Haase, H.; O. Silke and R. Lothar (2008). Zinc supplementation for the treatment or prevention of disease: Current status and future perspectives. Exp. Gerontol. 43: 394-408.

Helper, O.E. (1966). Manual of clinical laboratory methods. Thomos Spring Field. Illinois

Hyvarinen, A. and Nikkila, E.A. (1962). Determination of blood glucose with O. Toludine. Nut. Abst. Rev., 32: 589.

Juda, Th.M.; M.J. Ewad; K.J. Alhamdani and M.R. Judy (2007). Medical Journal of Babylon, 6: 45.

Kalafova, A.; N. Lukac; A. Capcarov; M. Schneidgenova; A. Kolesarova; J. Kovacik,; P. Cupka; P. Chrenek and P. Massanyi (2008). Účinokex perimentál nehopod anianiklu a inkunahlad inuhepatálny chenzýmov králikov. In Bezpečnost' a kvalitasurovín a potravínzborník vedeckýchprác z III. Vedeckej konferencie s medzináro dnouúčast'ouspojenej s 5. Výročímv zniku FBP SPU v Nitre, Nitra: Slovensk ápol'nohospo dárskau niverzita, s. 273-277.

Khan, T.A. and F. Zafar (2005). Hematological study in response to various doses of estrogen in broiler production. Int. J. Poult. Sci., 40:748-751.

Koracevic, D.; G. Koracevic, V. Djordjevic, S Andrejevic, and V Cosic (2001). Method for the measurement of antioxidant activity in human fluids. J. Clin. Pathol., 54: 356-61.

Liu, S.; M.J. Rovine; L. Cousino Klein and D.M. Almeida (2013). Synchrony of diurnal cortisol pattern in couples. J. Fam. Psychol. 27: 579-588.

Lucky, Z. (1977). Methods for the diagnosis of ish diseases. Ameruno Publishing Co, PVT, Ltd. New Delhi., Bomby, New Yourk.

Mahmood, H.M.A. and S.M. Sarmad (2016). Effect of Zinc Supplementation on some Physiological and Growth Traits in Local Male Rabbit; World's Vet. J., 6: 151-155.

Maria, C. Oliveira; D.M. Silva; and D.M. Dias (2013). Effect of feed restriction on organs and intestinal mucosa of growing rabbits, R. Bras. Zootec., 42: Viçosa July http://dx.doi.org.

Mastorakos, G. and I. Ilias (2003). Maternal and fetal hypothalamic pituitary adrenal axes during pregnancy and postpartum. Annals of the New York Academy of Sciences, 997: 136-149.

Matsuoka, T.; H. Mizuguchi; Y. Mizoguchi; T. Endho; R. Kamata; K. Fukuda; T. Ishikawa and Y. Asano (2009). Effects of restricted feeding on blood parameters in pregnant rabbits. J. Toxicol. Sci., 34: 129-137.

Matsuoka, T.; Y. Mizoguchi; K. Serizawa; T. Ishikura; H. Mizuguchi and Y. Asano (2006). Effects of stage and degree of restricted feeding on pregnancy out come in rabbits. J. Toxicol. Sci., 31: 166-175.

Maxwell, C.1. and S.L. Volpe (2007). Effect of zinc supplementation on thyroid hormone function. A case study of two college females. Ann. Nutr. Metab., 51: 188-194.

Mistry, H.D. and P.J. Williams (2011). The importance of antioxidant micronutrients in pregnancy. Oxid. Med. Cellu. Longev. 1-12.

Nafeaa, A.; A.E. Souad and F.H. Said (2011). Effect of feed restriction during pregnancy on performance and productivity of New Zealand White Rabbit does. Vet. Med. Int. Volume 2011, P, 1-5.

Nishiyama, S.; Y.S. Futagoishi; M. Matsukura; T. Nakamura; A. Higashi; M. Shinohara and Matsuda I. (1994). Zinc supplementation alters thyroid hormone metabolism in disabled patients with zinc deficiency. J. Am. Coll. Nutr., 13: 62-67. 
Nse-Abasi, N. E.; M. E. Williams; U. Akpabio and E. E.A. Offiong (2014). Haematological parameters and factors affecting their values. Sci. Edu. Cent. North America, 2: 37-47.

Palme, R.; P. Fischer; H. Schildorfer and M.N. Ismail (1996). Excretion of infused 14C steroid hormones via faeces and urine in domestic livestock. Anim. Reprod. Sci., 43: 43-63.

Peng, H.M. and M.J. Coon (1998). Regulation of rabbit cytochrome P4502E1 expression in Hep G2 cells by insulin and thyroid hormone. Mol. Pharmacol., 54: 740-747.

Powell, S. R. (2000). Antioxidant properties of zinc. J. Nutr. 130:1447S-1454S.

Prasad, A.S. (1995). Zinc: an overview. Nutri. 11: 93-9.

Reitman, S., and S. A., Frankel (1957). Colorimetric method for tile determination of serum glutamic oxalacetic and glutamic pyruvic transaminases. A in. J. Clin. Path. 28, 56

Richard, M.J., Portal, B., Meo, J., Coudray, C., Hadjian, A. and Favier, A. (1992). Malondialdehyde kit evaluated for determining plasma and lipoprotein fractions that react with thiobarbituric acid. Clin. Chem., 38: 704-709.

Rommers, J.M.; C. Boiti; G. Brecchia; R. Meijerhof; J.P. Noordhuizen; E. Decuypere and B. Kemp (2002). Metabolic adaptation and hormonal regulation in young rabbit does during long-term caloric restriction and subsequent compensatory growth. Animal Sci., 79: 255-264.

Rommers, J.M.; C. Boiti; G. Brecchia; R. Mejerhof; J.P. Noordhuizen and E. Decuypere (2004). Metabolic adaptation and hormonal regulation in young rabbit does during long-term caloric restriction and subsequent compensatory growth. Anim. Sci., 79: 255-264.

SAS (2002). SAS/ STAT User's guide statistics. SAS Institute INC., Cary, NC, USA.

Shaheen, A. A., and A. A. El-Fattah (1995). Effect of dietary zinc on lipid peroxidation, glutathione, protein thiols levels and superoxide dismutase activity in rat tissues. Int. J. Biochem. Cell Biol. 27:89-95.

Solomons, N.W. (1998). Mild human zinc deficiency produces an imbalance between cell-mediated and humoral immunity. Nutr. Rev. 56: 27-28.

Southon, S.; J.M. Gee; G.E. Bayliss; G.M. Wyatt; N. Horn and I.T. Johnson (1986). Intestinal microflora, morphology and enzyme activity in zinc-deficient and Zn-supplemented rats. Br. J. Nutr., 55: 603611.

Stein, E.A. (1986). Textbook of clinical chemistry, NW Tietz, ed. W.B. Saunders, Philadelphia, pp: 879886

Suda, A.K.; C.S. Pittman; T. Shimizu and J.B. Chambers (1978). The production and metabolism of 3, 5, $3^{\prime}$-triiodothyronine and 3, 3',5'-triiodothyronine in normal and fasting subjects. J. Clin. Endocrinol. Metab. 47: 1311-1319.

Tapiero, H. and K.D. Tew (2003). Trace elements in human physiology and pathology: zinc and metallothioneins. Biomed Pharmacother. 57: 399-411.

Tate, D. J., M. V. Miceli, and D. A. Newsome (1999). Zinc protects against oxidative damage in cultured human retinal pigment epithelial cells. Free Radic. Biol. Med. 26:704-713.

Tůmová, E., Z. Volek, D. Chodová, H. Härtlová, P. Makovický, J. Svobodová, T. A. Ebeid and L. Uhliŕrová (2016). The effect of 1-week feed restriction on performance, digestibility of nutrients and digestive system development in the growing rabbit. Animal, 10: 1-9.

Tůmová, E.; L. Zita; V. Skřivanová; A. Fučíková; M. Skřivan and M. Burešová (2007). Digestibility of nutrients, organ development and blood picture in restricted and ad libitum fed broiler rabbits. Archiv. für. Gefl., 71: 6-12.

Tupe, R. S., S. G. Tupe, and K. V. Tarwadi (2010). Effect of different dietary zinc levels on hepatic antioxidant and micronutrients indices under oxidative stress conditions. Metabol. 59:1603-1611.

Turturro, A.; P.H. Duffy and R.W. Hart (1993). Modulation of toxicity by diet and dietary macronutrient restriction. Mutation Res., 295: 151-162.

Underwood, E.J. and N.F. Suttle (1999). In: The mineral nutrition of livestock, $3^{\text {rd }}$ ed. CABI Publishing, CAB International, Wallingford, Oxon, UK. Technology, 93: 193-203. 


\section{Zeweil et al.}

Vallee, B. L., and K. H. Falchuk. (1993). The biochemical basis of zinc physiology. Physiol. Rev. 73:79118.

Wang, M. Q., W. J. Tao, S. S. Ye, Y.J. Du, C. Wang, and S. X. Shen (2012). Effects of dietary pharmacological zinc on growth, liver metallothionein, cu, zn-sod concentration and serum parameters in piglets. J. Anim. and Vet. Adv. 11:1390-1394.

Weichselaum, T.E. (1946). Method for determination of albumin in serum blood. Amer. J. Clin. Pathol., 16: 40 .

Wu, L.M.; M.H. Hu; X.H. Tong; H. Han and N. Shen (2012). Chronic unpredictable stress decreases expression of brain-derived neurotrophic factor (BDNF) in mouse ovaries: relationship to oocytes developmental potential. PLoS One 7(12): e52331.

Yassein .S.A.. and Sekena H. Abdel-Aziem (2011). Response of growing rabbits to feed restriction and some additives on performance, carcass and hepatic gene expression under Egyptian summer conditions. J. Agric. Sci. 3: 45-55.

Younas, M.S.; M.S. Butt Pasha and M. Shahid (2015). Effect of zinc fortified edible coated apricots on hematology in rabbits. J. Anim. Plant Sci., 25: 1140-1114.

Zearah, Sameerah A.; S.S. Hamadie and N.A.N. Awad (2016). Effect of zinc supplementation on thyroids hormones in sera of diabetic patients type 2. Int. Res. J. Nat. Sci., 4: 1-8.

Zhang, S.Y.; J.Z. Wang; J.J. Li; D.L. Wei and Sui (2011). Maternal restraint stress diminishes the developmental potential of oocytes. Biol Reprod., 84: 672-681.

Zlotkin, S. H., Atkinson, S. and Lockitch, G. (1995). Trace elements in nutrition for premature infants, March. 22, 223 - 240. 
تأثير التصويم وإضافة الزنك إلي العليقة على صورة الام والصورة الهرمونية والخصائص المضادة للأكسدة في ذكور الأرانب النامية

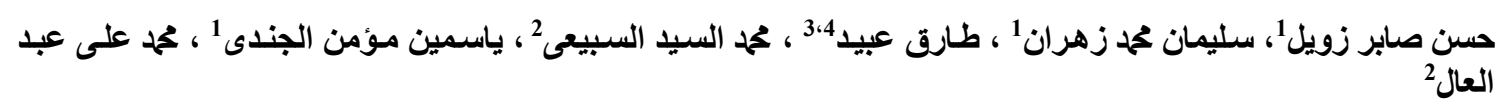

$$
1 \text { ق قسم الأنتاج الحيوانى والسمكي كلية الزراعة بسابا باثلـ جامعة الإسكندرية. }
$$

4 قسم إنتاج الحيوان وتربيته ، كلية الزراعة والطب البيطري ، جامعة القصيم ، السعودية.

تهذف هذه الدراسة إلي تقييم تأثير نظام تغذية (الصيام) وإضافة الزنك للعليقة على كلا من: صورة الام ومكوناته الكيميائية والصورة

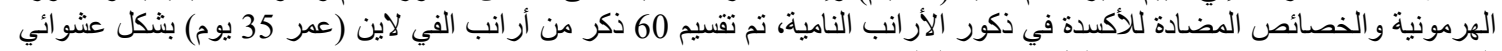
إلى 6 مجمو عات منساوية (10 ذكور لكل منهما) كالتالي:

(1) مجمو عة الضابطة أو الكتررول (تم تغذية الأر انب بنظام التخذية الحرة حتى الثنب الثبع على العليقة التجارية)

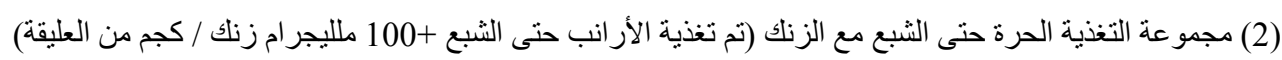

$$
\begin{aligned}
& \text { (3) مجمو عة التصويم لمدة } 24 \text { ساعة، } \\
& \text { (4) مجمو عة التصويم لددة } 48 \text { ساعة، } \\
& \text { (5) مجمو عة التصويم لمدة } 24 \text { ساعة+ } 100 \text { ملاعة لليجر ام زنكاعة / كجم من العليقة }
\end{aligned}
$$

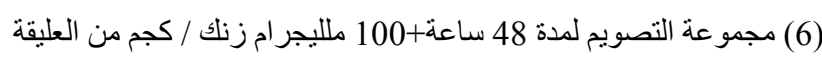

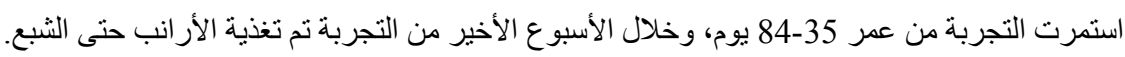

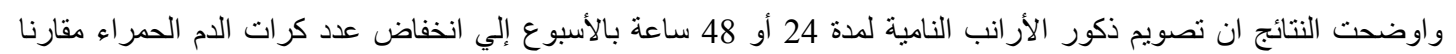

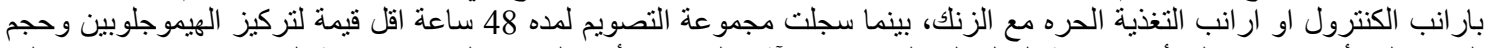

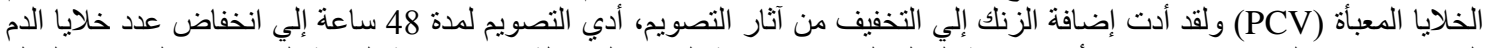

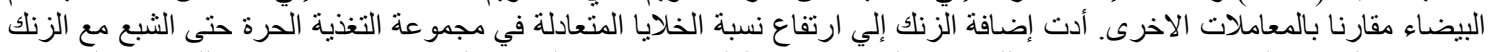

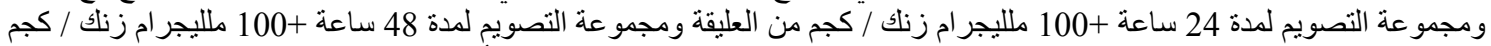

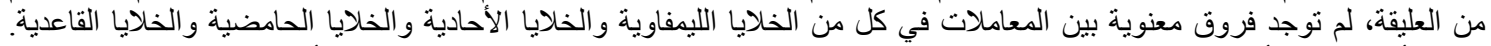

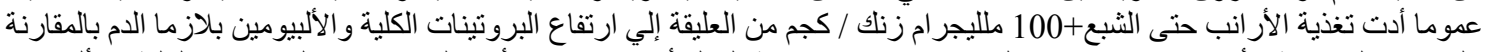

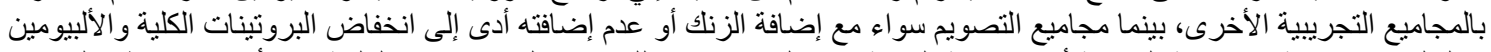

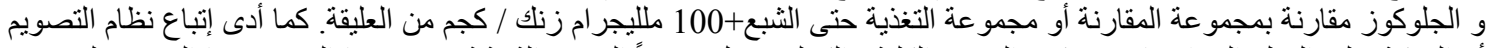

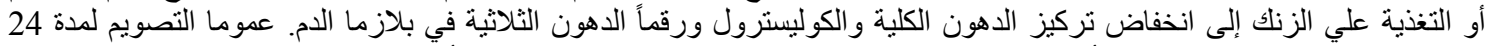

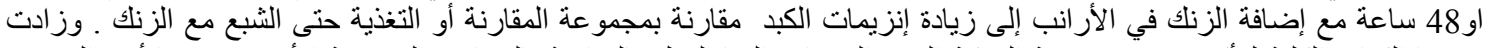

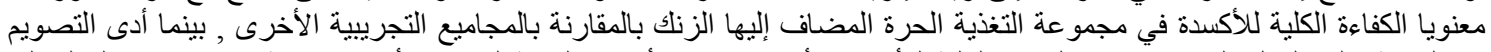

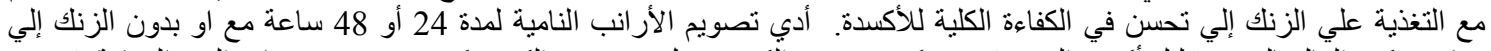

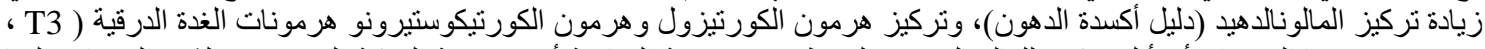

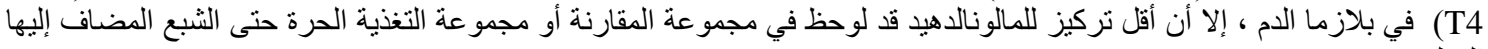

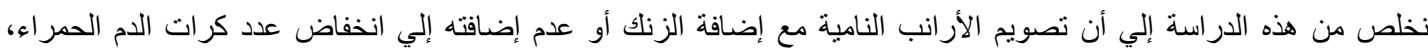

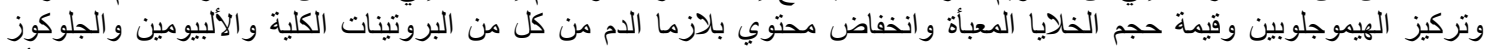

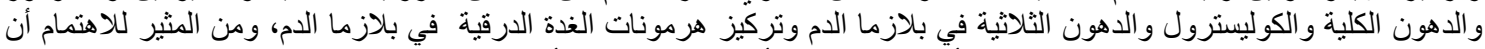

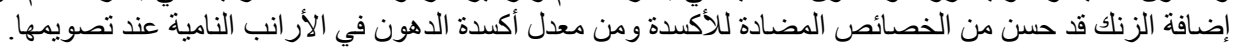

